\title{
Characterization of a brown Nostoc species from Java that is resistant to high light intensity and UV
}

\author{
Nola M. de Chazal and Geoffrey D. Smith \\ Author for correspondence: Geoffrey D. Smith. Tel: +61 6249 2843. Fax: +61 62490313.
}

Division of Biochemistry and Molecular Biology, School of Life Sciences, Faculty of Science, The Australian National University, ACT 0200, Australia

\begin{abstract}
A brown Nostoc species was isolated from a soil sample collected in Java, Indonesia. It has three physiological types of light-absorbing compounds: the photosynthetic pigments (chlorophyll a, carotenoids, phycocyanin, phycoerythrin and allophycocyanin), a brown pigment(s) and three UVabsorbing compounds. The organism undergoes complementary chromatic adaptation by varying its phycobilin content. It is resistant to photobleaching at high intensities of white light, and also to UV-C radiation, under which conditions a green-coloured Nostoc species (ATCC 27895) was killed. Synthesis of the brown pigment and UV-absorbing compounds was not observed at low oxygen levels. A brown pigment was released suddenly from cells during exponential growth, resulting in a deep brown-coloured medium. In addition, the absorption spectrum of the medium after pigment release had maxima in the UV region, at $256 \mathrm{~nm}, 314 \mathrm{~nm}$ and $400 \mathrm{~nm}$. The appearance of the UVabsorbing compounds coincided with the brown pigment release and with the disappearance from the vegetative cells of peripheral granules. The Nostoc species reduced acetylene, a measure of nitrogen fixation, in both the light and the dark periods when grown on a 12/12 h light/dark cycle. On a 4/20 h light/dark cycle fixation occurred predominantly in the light period. When grown on this restricted light regime, or at very low light intensity, the cells did not produce the brown pigment or the UV-absorbing compounds.
\end{abstract}

Keywords: Nostoc, cyanobacteria, UV-absorbing compounds, photobleaching, photosynthetic pigments

\section{INTRODUCTION}

Cyanobacteria, in general, have adapted for growth in relatively dim light conditions, and will often actively seek suitable niches of favourable light intensity for optimum growth (Donkor \& Häder, 1991). High solar radiation causes damage to their photosynthetic antennae and photobleaching of their cells (Carr \& Whitton, 1982).

The phycobiliproteins of cyanobacteria serve as their primary light-gathering antennae, and greatly extend the range of wavelengths of light absorbed (Gantt, 1981). Engelmann (1902) reported that the pigmentation of certain cyanobacteria could be modified by altering the light quality and it was later shown by Boresch (1922) that the colour change of cyanobacterial cells is attributable to a change in the phycoerythrin/phycocyanin ratio. This chromatic adaptation enables the cells to make maximum use of the particular wavelengths of light available in their environment and is particularly useful in underwater environments (Wyman \& Fay, 1986a, b). Such chromatic adaptation can only occur in those cyanobacteria that synthesize phycoerythrin (Tandeau de Marsac, 1977). Phycobiliproteins can also serve as nitrogen reserves in some species (Wyman et al., 1985; Heathcote et al., 1992).

Depletion of the ozone layer has resulted in an increase in penetration of the shorter and most biologically injurious wavelengths $(280-320 \mathrm{~nm})$ of ultraviolet radiation (UV) (Smith et al., 1992). Some cyanobacteria synthesize UVabsorbing compounds that appear to act as sunscreens and enable them to inhabit environments that are exposed to intense solar radiation (Garcia-Pichel \& Castenholz, 1991; Garcia-Pichel et al., 1992, 1993; Matsunaga et al., 1993; Scherer et al., 1988). Shibata (1969) isolated UV-absorbing substances that were later identified by Dunlap \& Chalker (1986) as a series of mycosporine-like amino acids which in marine organisms absorb UV radiation between 310 and $360 \mathrm{~nm}$ (Dunlap et al., 1989). Mycosporine-like amino acids in cyanobacteria have also been reported by Garcia- 
Pichel \& Castenholz (1993). They are water-soluble compounds that absorb in the UV-B region of the spectrum. Scherer et al. (1988) reported a UV-A/Babsorbing compound in Nostoc commune that was watersoluble and located outside the cells, in the polysaccharide matrix of the colony. An extracellular UV-A-absorbing pigment, scytonemin, was reported by Garcia-Pichel \& Castenholz (1991). Matsunaga et al. (1993) reported a UVA-absorbing biopterin glucoside in a marine Oscillatoria species.

In this paper we describe the characterization of a brown Nostoc species that is resistant to high light intensity and UV.

\section{METHODS}

Cyanobacterial isolation and growth. The Nostoc sp. described here was from a soil crust sample collected in February 1992 from a village in Java, Indonesia. It was rendered unialgal using the light variation methodology of de Chazal et al. (1992), the sample being first enriched for cyanobacteria by growth in the nitrogen-free medium of Allen \& Arnon (1955), diluted to $1 / 8$ strength of all components except phosphate, and with a fourfold increase in $\mathrm{NiSO}_{4}$. Nostoc sp. ATCC 27895 was obtained from the American Type Culture Collection. For oxic growth the cells were sparged with $0.3 \% \mathrm{CO}_{2}$ in air at $25^{\circ} \mathrm{C}$ (unless otherwise stated) and for anoxic growth they were sparged with $0.3 \% \mathrm{CO}_{2}$ in $\mathrm{N}_{2}$. The cells were illuminated with banks of fluorescent lights (Daday et al., 1977). For photobleaching experiments at 'high light intensity', the cells were grown in tall, narrow ( $8 \mathrm{~cm}$ diameter) flasks placed on aluminium foil to provide a reflective surface and surrounded by vertical banks of fluorescent tubes; for other experiments at this light intensity the cells were grown in Erlenmeyer flasks. The light intensity was, in this lighting configuration, difficult to define precisely because the cells received light from $360^{\circ}$; the unidirectional intensity measured at one side of the flask was $200 \mu \mathrm{E} \mathrm{s}^{-1} \mathrm{~m}^{-2}$ photosynthetically active radiation. In the experiments at the 'high light intensity' the growth flasks were cooled by a fan in order to maintain the growth temperature of $25^{\circ} \mathrm{C}$; in other experiments the cells were deliberately temperature-stressed by switching off the fan, in which case the cultures reached a temperature of $39^{\circ} \mathrm{C}$. Cell growth was measured with a Klett-Summerson colorimeter (no. 66 filter; Mallette, 1969).

Cell extraction. Cells were concentrated by centrifugation $\left(27000 \mathrm{~g}, 15 \mathrm{~min}, 4^{\circ} \mathrm{C}\right)$, disrupted using a French pressure cell at $138 \mathrm{MPa}$ and cell debris was subsequently removed by centrifugation $\left(27000 \mathrm{~g}, 15 \mathrm{~min}, 4^{\circ} \mathrm{C}\right)$. The brown pigment fraction was pelleted by further centrifugation in a Beckman TL-100 ultracentrifuge $\left(81000 \mathrm{~g}, 1 \mathrm{~h}, 4^{\circ} \mathrm{C}\right)$. The UV-absorbing compounds were extracted by centrifuging cells at $1000 \mathrm{~g}$, aspirating the supernatant, then extracting the pellet of cells with water at $50{ }^{\circ} \mathrm{C}$ for $30 \mathrm{~min}$ and centrifuging (Scherer et al., 1988).

Assays. The nitrogen-fixing capacity of the cells was determined by the acetylene reduction assay as described previously (Lambert \& Smith, 1980). Phycoerythrin, phycocyanin and allophycocyanin were extracted and determined by the method of Tandeau de Marsac (1977). The scytonemin assay method was that of Garcia-Pichel \& Castenholz (1991). The assay for proanthocyanidins (condensed tannins) was that of Sarker \& Haworth (1976) and the cyanophycin assay was that of Daday et al. (1988).
Spectra. Spectra of growth media were measured on the supernatants obtained after centrifuging the cells, using a Varian Techtron model 635 spectrophotometer attached to a chart recorder.

Cell dry weights. These were determined by centrifuging a homogeneous mixture of cells $(5-10 \mathrm{ml})$, washing once with water and then drying in preweighed tubes at $85^{\circ} \mathrm{C}$.

Exposure to UV. Cells in exponential growth were washed three times with water and added to $250 \mathrm{ml}$ water (in which cells were viable for many days; the growth medium was not used because it partially absorbed UV) to a concentration of 20 Klett units in flat crystal dishes, $15 \mathrm{~cm}$ diameter, and stirred with a magnetic bar. They were placed $33 \mathrm{~cm}$ below each of the following lamps: a cool white fluorescent globe, a National Electric Company $40 \mathrm{~W}$ T10 black light tube with an emission range of $304-450 \mathrm{~nm}$ and peak emission at $366 \mathrm{~nm}$ (UV-A), and a Philips TL 40W/12 UV tube with an emission range of 260-360 nm and maximum emission in the UV-B region. The cells were covered with a Perspex sheet $2 \mathrm{~mm}$ thick that specifically blocked UV-C. For experiments with UV-C alone, the cells were exposed to a single germicidal lamp (253.7 nm emission). The viability of cells was determined qualitatively by monitoring their colour and trichome damage, and also by streaking them on to $1 \%(\mathrm{w} / \mathrm{v})$ agar plates (prepared in the growth medium). In the latter case, cells were plated after $2.5 \mathrm{~h}$ exposure to the UV and then daily for $3 \mathrm{~d}$; the plates were then placed in continuous light at $25^{\circ} \mathrm{C}$ and checked for colony growth after a further week.

Light measurement. Light intensity was measured as photosynthetically active radiation using a Li-COR meter, model LI$185 \mathrm{~B}$.

Electron microscopy. Cells were fixed in $2.5 \%(\mathrm{v} / \mathrm{v})$ glutaraldehyde, $4 \%(\mathrm{v} / \mathrm{v})$ formaldehyde in $0.1 \mathrm{M}$ sodium cacodylate buffer with $0.14 \mathrm{M}$ sucrose $(\mathrm{pH} 7 \cdot 2)$, fixed in $1 \%$ $(\mathrm{w} / \mathrm{v})$ osmium tetroxide in the same buffer, washed, dehydrated through an ethanol series and embedded in Araldite (CibaGeigy). Ultrathin sections were cut, stained for 15-20 min with uranyl acetate, washed, stained for 5-10 min with lead citrate, washed again and allowed to dry before viewing in an Hitachi H600 transmission electron microscope at $75 \mathrm{kV}$.

\section{RESULTS}

\section{General characterization of the brown Nostoc species}

Cyanobacterial soil crusts were inoculated into nitrogenfree medium and grown at a light intensity of $80 \mu \mathrm{E} \mathrm{s}^{-1}$ $\mathrm{m}^{-2}$. In such a mixed culture the Nostoc grew as isolated bundles within the resulting matted cyanobacterial mixture. Assignment as a Nostoc species was based on the microscopic criteria given by Rippka et al. (1979). The vegetative cells were pale brown and the heterocysts were green. The organism initially represented only a small proportion of the mixed culture. When such mixed cultures were subcultured several times by washing and inoculating into fresh medium at 'high light intensity' and maintained at $25^{\circ} \mathrm{C}$ with a fan (see Methods), the brown Nostoc became the predominant species together with small numbers of a Synechococcus species that could be removed by repeated dilution streaking on $1 \%$ agar plates or by movement of the Nostoc on a scored agar plate (see de Chazal et al., 1992, for details of methodology).

It was observed visually that the cells synthesized an intense brown pigment which was released suddenly at a 

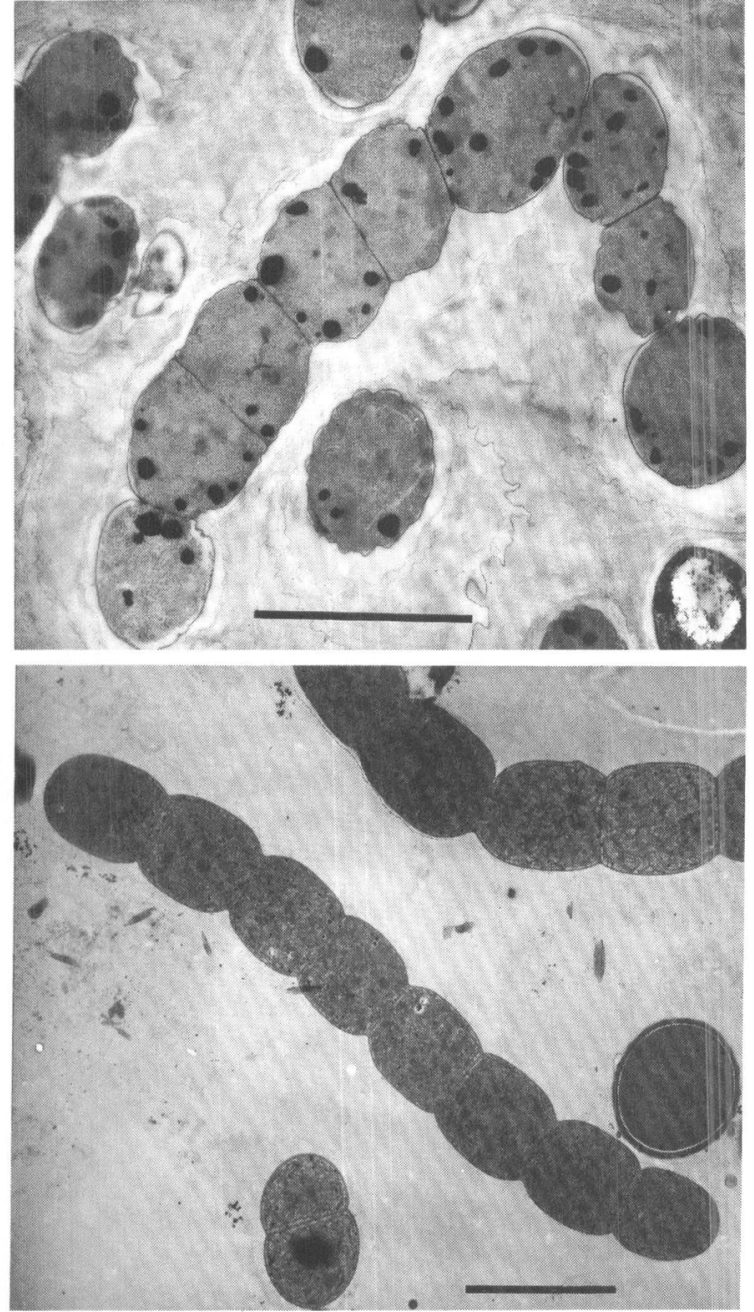

Fig. 1. Electron micrographs of brown Nostoc cells before (top) and after (bottom) pigment release. Associated with this release can be seen the disappearance of granules from the cells. The cells were grown at the 'high light intensity' as defined in Methods. Bars, $5 \mu \mathrm{m}$.

certain stage of exponential growth, resulting in a deep brown-coloured medium. The Nostoc showed an interesting adaptation with respect to its pigmentation: under normal growth conditions it was brown, but when grown at very low light intensity $\left(3.5 \mu \mathrm{E} \mathrm{s}^{-1} \mathrm{~m}^{-2}\right)$ or on a $4 / 20 \mathrm{~h} \mathrm{light} /$ dark cycle it became green. Microscopic examination of the brown cells revealed the presence of large intracellular granules (Fig. 1) that were not present in green cells. These granules did not fluoresce when examined in a confocal microscope with excitation wavelengths of 488,568 or $647 \mathrm{~nm}$.

In addition to the brown pigment, both brown and green cells contained phycocyanin, allophycocyanin and phycoerythrin, although the content of these biliprotein pigments was significantly less in green cells $(0.021,0.006$ and 0.004 versus $0.066,0.040$ and $0.074 \mathrm{mg}(\mathrm{mg}$ cell dry weight $)^{-1}$, respectively). There was no measurable temporal change in the content of these pigments in cells grown either on a $12 / 12 \mathrm{~h}$ or a $4 / 20 \mathrm{~h}$ light/dark cycle (results not shown), suggesting that the biliproteins do not function as a dynamic nitrogen store across the diurnal cycle (Carr, 1988). Nevertheless, when cells were incubated in the dark for a prolonged period, the content of phycocyanin, allophycocyanin and phycoerythrin decreased from 0.028 to 0.009 , from 0.017 to 0.004 and from 0.034 to $0.008 \mathrm{mg}$ ( $\mathrm{mg}$ cell dry weight $)^{-1}$, respectively. The cells were still viable after three weeks of darkness. The organism did not produce significant cyanophycin (as measured biochemically) under any of the growth conditions described here (results not shown).

When grown on a $12 / 12 \mathrm{~h}$ light/dark cycle the brown Nostoc reduced acetylene, reflecting its capacity for nitrogen fixation, both in the light and in the dark (results not shown). Clearly, under these conditions the cells can maintain throughout most of the dark period a sufficient supply of those photosynthetically generated chemicals that provide reductant and ATP for the nitrogenase. The rate of acetylene reduction was related inversely to the intensity of the brown colour of the cells; dark brown cells needed a higher light intensity to maintain a given rate of acetylene reduction than did green cells. When green cells were incubated on a $4 / 20 \mathrm{~h}$ light/dark cycle, acetylene reduction occurred mainly in the light period (results not shown).

\section{Properties of the brown pigment}

An absorption spectrum of a total cell extract, which was brown, is shown in Fig. 2(a). When this cell extract was centrifuged at $81000 \mathrm{~g}$ for $60 \mathrm{~min}$, to pellet chlorophyllcontaining membrane fractions (Tandeau de Marsac, 1977), the brown pigmentation was found in the pellet, leaving a pink supernatant, the spectrum of which is also shown in Fig. 2(a); the two peaks in the supernatant represent phycoerythrin and phycocyanin, and so clearly the brown colour is due to some other pigment. Interestingly, when the brown medium that had been obtained after centrifuging whole cells was similarly centrifuged, the brown coloration remained in the supernatant, indicating that the excreted pigment(s) was different, either chemically or in its attachment to cellular particles. Attempts to extract the brown pigment were unsuccessful; it was always found with the chlorophyll fraction. The difference spectrum calculated by subtracting the two spectra shown in Fig. 2(a) showed a shoulder at approximately $480 \mathrm{~nm}$ (Fig. 2b). When a normalized spectrum of pure chlorophyll $a$ was in turn subtracted from this difference spectrum, a broad peak with an absorbance maximum at $480 \mathrm{~nm}$ was revealed (Fig. 2b). This is presumed to represent the brown pigment. Its nature is unknown. It is not tannin since no proanthocyanidins (condensed tannins) were detected. It is highly anionic, binding very strongly to DEAEcellulose at $\mathrm{pH} 7 \cdot 6$.

\section{Properties of the UV-absorbing compounds}

The absorption spectrum of the medium after the spontaneous release of brown pigment from cells grown under oxic conditions, but not anoxic ones, revealed 


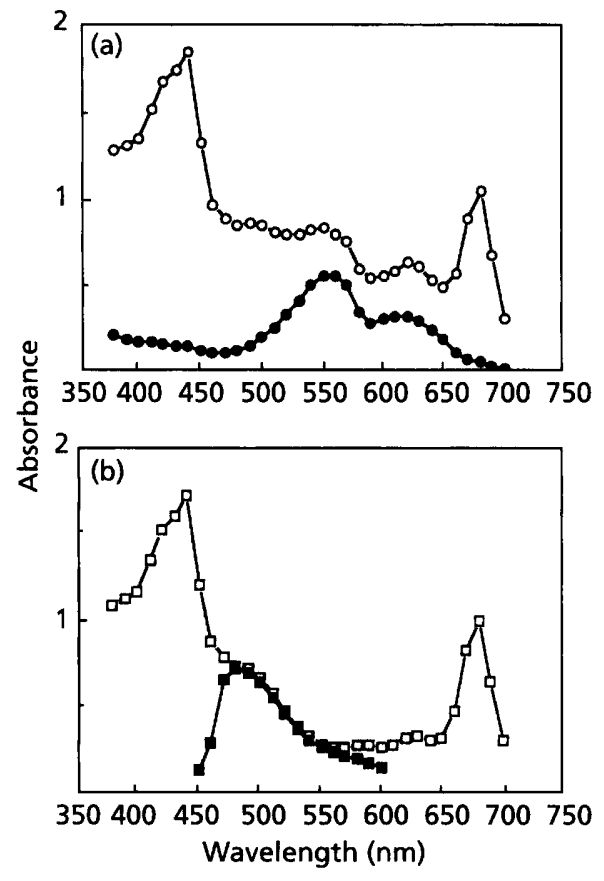

Fig. 2. Absorption spectrum of a total cell extract, which was brown, obtained by disrupting the cells in a French pressure cell and removing cell debris by centrifugation $(O, a)$. When this cell extract was further centrifuged at high speed $(81000 \mathrm{~g}$, $60 \mathrm{~min}$ ) the brown pigmentation was found in the pellet, leaving a pink supernatant, the spectrum of which $(O)$ is also shown in (a). The difference spectrum calculated by subtracting the two spectra from (a) is shown ( $\square$ ) in (b). When a normalized spectrum of pure chlorophyll a was subtracted from this difference spectrum a broad peak with an absorbance maximum at $480 \mathrm{~nm}$ was revealed $(\boldsymbol{G}, \mathrm{b})$. This is presumed to represent the brown pigmentation.

peaks in the UV region with maxima at $256 \mathrm{~nm}$ (UV-C), $314 \mathrm{~nm}$ (UV-B) and $400 \mathrm{~nm}$ (UV-A) (Fig. 3). The appearance of the UV-absorbing compounds in the medium coincided with the release of the brown pigment. When brown cells were extracted into water at $50^{\circ} \mathrm{C}$ the spectrum of the extract revealed only the peak with an absorption maximum at $256 \mathrm{~nm}$ (result not shown). With green cells this peak was not found. No scytonemin was detected in brown cells. HPLC analysis (Dunlap \& Chalker, 1986) of lyophilized cells revealed three distinct polar compounds (with maxima at $314 \mathrm{~nm}, 280 \mathrm{~nm}$ and $256 \mathrm{~nm}$ ) which bore no relationship to mycosporin-like amino acids.

\section{Physiological aspects of pigment and UV-absorbing compound formation and release}

Production of the brown and UV-absorbing compounds appeared to be a response of the cells to light. When green cells were used to initiate growth they turned brown and, after a certain time of exponential growth, were clearly observed visually to suddenly release both the brown pigment and the UV-absorbing compounds into the growth medium. The time of release in the growth cycle varied with the light intensity. A typical result for the UV-

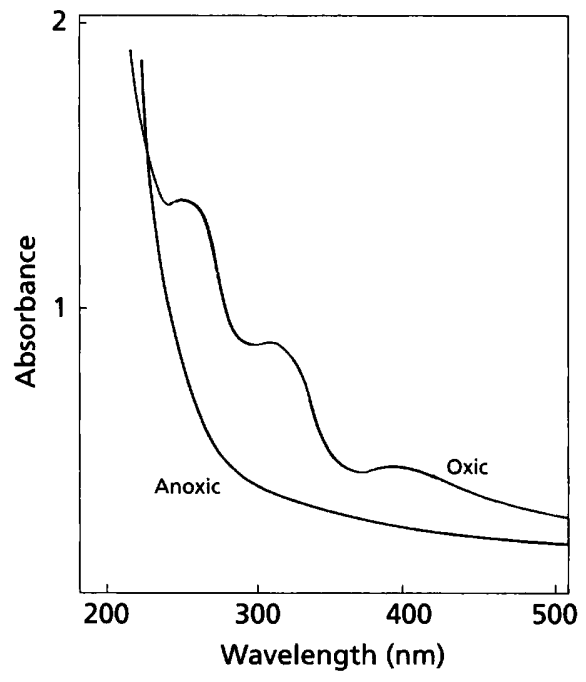

Fig. 3. Absorption spectra of growth media obtained after centrifuging cells that had been grown to $125 \mathrm{Klett}$ units under either oxic (brown cells) or anoxic (orange-green cells) conditions at 'high light intensity' as defined in Methods.

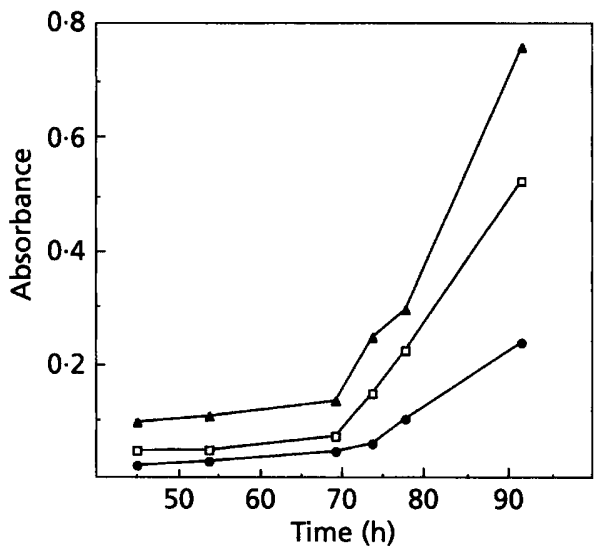

Fig. 4. Sudden release of UV-absorbing compounds from exponential-phase cells grown under oxic conditions at 'high light intensity'. Absorbance was measured at $400 \mathrm{~nm}$ ()), $315 \mathrm{~nm}(\square)$ and $255 \mathrm{~nm}(\Delta)$.

absorbing compounds is shown in Fig. 4; at $70 \mathrm{~h}$ the cells were growing with a doubling time of $12 \mathrm{~h}$. The brown pigment release appeared to be related to the disappearance of granules from vegetative cells as observed by electron microscopy (Fig. 1). These granules subsequently re-formed within the cells and were released again; this was more readily observed when the cells were washed and resuspended in fresh medium. When brown cells were inoculated for growth on a $4 / 20 \mathrm{~h}$ light/dark cycle the supernatant remained clear and the cells turned green. If green cells were placed on such a cycle, they remained green and the supernatant remained colourless.

Oxygen appeared to be necessary for synthesis of both the brown and the UV-absorbing compounds since reduction 
in oxygen levels prevented their formation; cells sparged with nitrogen $/ 0.3 \% \mathrm{CO}_{2}$ during growth turned orangegreen and did not release either brown pigment or UVabsorbing compounds (results not shown).

\section{Response of cells to UV}

When compared with a green Nostoc species (ATCC 27895) a striking resistance of the brown species to UV was observed. Nostoc sp. ATCC 27895 was rapidly photobleached and killed by UV-C, whereas brown cells of the Javan isolate survived after a $22 \mathrm{~h}$ exposure. UV-C did, however, turn the brown Nostoc cells green and caused granules to appear in the vegetative cells. Interestingly, exposure to UV-C also increased the resistance of the cells during subsequent exposure to UVA together with UV-B; such cells were still viable after $56 \mathrm{~h}$, whereas cells not previously exposed to UV-C did not produce granules, were photo-oxidized and almost all were killed within $50 \mathrm{~h}$.

\section{Resistance to photobleaching by white light}

The brown Nostoc was able to grow at elevated temperature $\left(39^{\circ} \mathrm{C}\right)$ combined with high light intensity. When cells were incubated under oxic conditions on a $12 / 12 \mathrm{~h}$ light/dark cycle at 'high light intensity' (see Methods), and fanned to maintain them at ambient temperature $25^{\circ} \mathrm{C}$, they were resistant to photobleaching and turned dark brown over the course of 2 or $3 \mathrm{~d}$, during which time granules appeared in the vegetative cells (cf. Fig. 1). Cells grown under anoxic conditions were also resistant to photobleaching but no granules appeared in the vegetative cells. A similar resistance was observed in cultures grown in continuous light, both at $25^{\circ} \mathrm{C}$ and $39^{\circ} \mathrm{C}$.

In order to provide control observations we did similar experiments on the green Nostoc sp. (ATCC 27895). By contrast with the brown species it was susceptible to photobleaching. In continuous 'high light intensity', under both oxic and anoxic growth conditions, the cells survived at $25{ }^{\circ} \mathrm{C}$, but at $39{ }^{\circ} \mathrm{C}$ they photobleached within $3 \mathrm{~d}$ as observed visually by the cells turning yellow (cf. Barabás \& Laczkó, 1985) followed by the trichomes breaking up. On a $12 / 12 \mathrm{~h}$ light/dark cycle both oxic and anoxic cells survived at $25{ }^{\circ} \mathrm{C}$ but at $39^{\circ} \mathrm{C}$ the oxic cells remained green and survived whereas the anoxic cells photobleached within $3 \mathrm{~d}$.

\section{DISCUSSION}

The Nostoc species described here has a number of interesting properties that presumably enable it to survive and grow in the tropical environment, with its intense solar radiation, and successfully compete with other species (it became the dominant organism in a cyanobacterial mixture exposed to high light intensity). These properties include nitrogen fixation, resistance to photobleaching under both oxic and anoxic conditions at elevated temperature, and the presence of three types of light-absorbing compounds: the photosynthetic lightharvesting pigments (including chlorophylls, carotenoids and phycobilins), a brown pigment, and UV-absorbing compounds. The brown Nostoc is clearly different in several respects from Nostoc commune, which also has UVabsorbing compounds. Unlike the brown Nostoc, N. commune has a life cycle (Fogg et al., 1973) and has a different spectrum in the UV region (Scherer et al., 1988). Although the brown pigmentation of cells was dominant under most growth conditions, a green form of the organism was observed under the following conditions: growth on a light/dark cycle with a long dark period $(4 / 20 \mathrm{~h})$; growth while sparging with $0.3 \% \mathrm{CO}_{2}$ in nitrogen; maintenance at very low light intensity and exposure to UV-C.

The ability of the cells to vary their phycoerythrin/ phycocyanin ratio allows regulation of the balance of wavelengths of light absorbed by the organism, a phenomenon termed chromatic adaptation (Tandeau de Marsac, 1977). There was no evidence that the phycoerythrin has a major function as a nitrogen storage compound, as for example in the marine cyanobacterium Synechococcus (Wyman et al., 1985), although this organism may be the exception rather than the rule. The brown Nostoc has a phycoerythrin/phycocyanin ratio of approximately one and both of these pigments decreased upon prolonged starvation in the dark. These pigments appeared to decline more slowly during nitrogen starvation than did phycocyanin in Anacystis nidulans (Allen \& Smith, 1969), an organism in which phycocyanin appears to play a more dynamic role as a nitrogen storage compound. Phycoerythrin, phycocyanin and allophycocyanin all remained constant across the light/dark cycle. Interestingly, it has been reported that many phycoerythrin-containing cyanobacteria are markedly light-sensitive (Tandeau de Marsac, 1977), whereas the brown Nostoc investigated here thrives at high light intensity and is strikingly resistant to photo-oxidation.

An interesting property of the brown Javan Nostoc is the sudden release of brown pigment during growth. This pigment may be excreted as a waste-product generated from a form that functions as an antioxidant; it is not synthesized when cells are sparged with gas not containing oxygen. It is also possible that the brown pigment is synthesized constitutively and loss of brown pigmentation is a stress response of the cells. Extracellular products, including pigments, of cyanobacteria are well known (Carr \& Whitton, 1982) but little is known about the physiology of their release. It may be that there is more than one brown pigment, and the form which is excreted is distinct from that which is tightly bound in the chlorophyll fraction and pelleted at high centrifugal force. It is interesting to speculate on whether the latter functions as an accessory light-harvesting pigment.

The brown Nostoc was resistant to photobleaching under conditions of high continuous light intensity and elevated temperature $\left(39^{\circ} \mathrm{C}\right)$, under which conditions a green Nostoc sp. (ATCC 27895) photobleached. The latter organism did not photobleach when incubated under oxic conditions on a $12 / 12 \mathrm{~h}$ light/dark cycle at the elevated 
temperature of $39^{\circ} \mathrm{C}$; one possible explanation is that a period of respiration in the dark allows recovery. It should be noted in relation to experiments with the green Nostoc sp. (ATCC 27895), and other experiments that we have done on Anabaena cylindrica (results not shown), that photobleaching is a combined effect of high light intensity and elevated temperature; the photobleaching described for the latter organism by Laczkó \& Barabás (1981) was partly due to a temperature effect in continuous light.

In addition to their resistance to high white light intensity, the brown cells were also resistant to UV, particularly UV-C. Exposure of the trichomes to UV-C increased the subsequent resistance of the Nostoc to UV-A plus -B. The physiological significance of this observation is not clear because UV-C is absorbed by the Earth's atmosphere. The nature of the UV-absorbing compounds remains to be determined.

The brown Nostoc fixed nitrogen in both the light and a substantial period in the dark when grown on a $12 / 12 \mathrm{~h}$ light/dark cycle, in contrast to Nostoc UCSB9 (Khamees et al., 1987). It presumably does not therefore need nitrogen reserve compounds, such as the phycobilins or cyanophycin, to integrate growth across the light and dark periods on the normal diurnal cycle (Carr, 1988). Cyanobacteria appear to vary considerably in their capacities to support dark nitrogen fixation (Khamees et al., 1987). When the brown Nostoc was grown on a $4 / 20 \mathrm{~h}$ light/dark cycle, fixation decreased much earlier in the dark period (results not shown).

In summary, the organism described here has properties that indicate it is well adapted to the tropical environment from which it was isolated. Further work is necessary to chemically characterize the pigments, and to determine their relationship to the intracellular granules and the effect of pigmentation on nitrogen fixation.

\section{ACKNOWLEDGEMENTS}

We thank the Australian Research Council for a research grant. We thank Dr G. Tanner for assaying for tannins, Dr B. Chalker for the HPLC analysis and helpful conversations, Wafa ElAdhami and Professor J. Elix for advice, Dr Anne Cleary for the confocal microscopy and Lily Shen (electron microscopy unit, $\mathrm{ANU}$ ) for the electron microscopy.

\section{REFERENCES}

Allen, M. B. \& Arnon, D. I. (1955). Studies on nitrogen-fixing bluegreen algae. I. Growth and nitrogen fixation by Anabaena cylindrica Lemm. Plant Pbysiol 30, 366-372.

Allen, M. M. \& Smith, A. J. (1969). Nitrogen chlorosis in bluegreen algae. Arch Mikrobiol 69, 114-120.

Barabás, K. \& Laczkó, I. (1985). Characterization of the photosynthetic electron transport chain in normal and photobleached Anabaena cylindrica by flash spectroscopy. $J$ Bioenerg Biomembr 17, 123-133.

Boresch, K. (1922). Die komplementäre chromatische Adaptation. Arch Protistenk 44, 1-70.

Carr, N. G. (1988). Nitrogen reserves and dynamic reservoirs in cyanobacteria. In Biochemistry of the Algae and Cyanobacteria (Annu
Proc Pbytochem Soc Eur, vol. 28), pp. 13-21. Edited by L. T. Rogers \& J. R. Gallon. Oxford: Clarendon Press.

Carr, N. G. \& Whitton, B. A. (1982). Interactions of cyanobacteria with light. In The Biology of Cyanobacteria (Bot Monogr vol. 19), pp. 9-45. Edited by N. G. Carr \& B. A. Whitton. Oxford: Blackwell Scientific Publications.

de Chazal, N. M., Smaglinski, S. \& Smith, G. D. (1992). Methods involving light variation for isolation of cyanobacteria: characterization of isolates from central Australia. Appl Environ Microbiol 58, 3561-3566.

Daday, A., Platz, R. A. \& Smith, G. D. (1977). Anaerobic and aerobic hydrogen gas formation by the blue-green alga Anabaena cylindrica. Appl Environ Microbiol 34, 478-483.

Daday, A., Mackerras, A. H. \& Smith, G. D. (1988). A role for nickel in cyanobacterial nitrogen fixation and growth via cyanophycin metabolism. J Gen Microbiol 134, 2659-2663.

Donkor, V. \& Häder, Donat-P. (1991). Effects of solar and ultraviolet radiation on motility, photomovement and pigmentation in filamentous, gliding cyanobacteria. FEMS Microbiol Ecol 86, 159-168.

Dunlap, W. C. \& Chalker, B.E. (1986). Identification and quantitation of near-u.v. absorbing compounds (SW-320) in a hermatypic scleractinian. Coral Reefs 5, 155-159.

Dunlap, W. C., Williams, D. McB., Chalker, B. E. \& Banaszak, A. T. (1989). Biochemical photoadaptation in vision: u.v.-absorbing pigments in fish eye tissues. Comp Biochem Pbysiol 93B, 601-607.

Engelmann, T.W. (1902). Ueber experimentelle Erzeugung zweckmässiger Aenderungen der Färbung pflanzlicher Chromophylle durch farbiges Licht. Arch Anat Physiol Abstr, 333-335.

Fogg, G. E., Stewart, W. D. P., Fay, P. \& Walsby, A. E. (1973). The Blue-Green Algae. London \& New York: Academic Press.

Gantt, E. (1981). Phycobilisomes. Annu Rev Plant Pbysiol 32, 327-347.

Garcia-Pichel, F. \& Castenholz, R. W. (1991). Characterization and implications of scytonemin, a cyanobacterial sheath pigment. $J$ Phycol 27, 395-409.

Garcia-Pichel, F. \& Castenholz, R. W. (1993). Occurrence of u.v.absorbing, mycosporine-like compounds among cyanobacterial isolates and an estimate of their screening capacity. Appl Environ Microbiol 59, 163-169.

Garcia-Pichel, F., Sherry, N. D. \& Castenholz, R. W. (1992). Evidence for an ultraviolet sunscreen role of the extracellular pigment scytonemin in the terrestrial cyanobacterium Chlorogloepsis sp. Photochem Photobiol 56, 17-23.

Garcia-Pichel, F., Wingard, C. E. \& Castenholz, R. W. (1993). Evidence regarding the u.v.-sunscreen role of a mycosporine-like compound in the cyanobacterium Gloeocapsa sp. Appl Environ Microbiol 59, 170-176.

Heathcote, P., Wyman, M., Carr, N. G. \& Beddard, G. S. (1992). Partial uncoupling of energy transfer from phycoerythrin in the marine cyanobacterium Synechococcus sp. WH7803. Biochim Biophys Acta 1099, 267-270.

Khamees, H. S., Gallon, J. R. \& Chaplin, A. E. (1987). The pattern of acetylene reduction by cyanobacteria grown under alternating light and darkness. Br Pbycol J 22, 55-60.

Laczkó, I. \& Barabás, K. (1981). Hydrogen evolution by photobleached Anabaena cylindrica. Planta 153, 312-316.

Lambert, G. R. \& Smith, G. D. (1980). Hydrogen metabolism by filamentous cyanobacteria. Arch Biochem Biophys 205, 36-50.

Mallette, M. F. (1969). Evaluation of growth by physical and chemical means. Methods Microbiol 1, 521-566. 
Matsunaga, T., Burgess, J. G., Yamada, N., Komatsu, K., Yoshida, S. \& Wachi, Y. (1993). An ultraviolet (uv-a) absorbing biopterin glucoside from the marine planktonic cyanobacterium Oscillatoria sp. Appl Microbiol Biotechnol 39, 250-253.

Rippka, R., Deruelles, J., Waterbury, J. B., Herdman, M. \& Stanier, R. Y. (1979). Generic assignments, strain histories and properties of pure cultures of cyanobacteria. J Gen Microbiol 111, 1-61.

Sarker, S. K. \& Haworth, R. E. (1976). Specificity of the vanillin test for flavonols. I Agric Food Chem 24, 317-320.

Scherer, S., Chen, T. W. \& Böger, P. (1988). A new uv-a/b protecting pigment in the terrestrial cyanobacterium Nostoc commune. Plant Pbysiol 88, 1055-1057.

Shibata, K. (1969). Pigments and a uv-absorbing substance in corals and a blue-green alga living in the barrier reef. Plant Cell Pbysiol 10, 325-335.

Smith, R. C., Prézelin, B. B., Baker, K. S., Bidigare, R. R., Boucher, N. P., Coley, T., Karentz, D., Macintyre, S., Matlick, H. A., Menzies, D., Ondrusek, M., Wan, Z. \& Waters, K. J. (1992). Ozone depletion: ultraviolet radiation and phytoplankton biology in Antarctic waters. Science 255, 952-959.

Tandeau de Marsac, N.T. (1977). Occurrence and nature of chromatic adaptation in cyanobacteria. $J$ Bacteriol 130, 82-91.

Wyman, M. \& Fay, P. (1986a). Underwater light climate and the growth and pigmentation of planktonic blue-green algae (cyanobacteria). I. The influence of light quantity. Proc R Soc Lon Ser B Biol Sci 227, 367-380.

Wyman, M. \& Fay, P. (1986b). Underwater light climate and the growth and pigmentation of blue-green algae (cyanobacteria). II. The influence of light quality. Proc R Soc Lon Ser B Biol Sci 277, 381-393.

Wyman, M., Gregory, R. P. F. \& Carr, N. G. (1985). Novel role for phycoerythrin in a marine cyanobacterium, Synechococcus strain DC2. Science 230, 818-820.

Received 8 July 1994; accepted 1 August 1994. 